JOSAR, Vol. 1 No. 2 September, 2018; p-ISSN: 2502-8251; e-ISSN: 2503-1155

Copyrights@ Balitar Islamic University, Blitar-Indonesia https://ejournal.unisbablitar.ac.id/index.php/josar

\title{
RADICALISM AND PEACE IN THE WOMEN'S WORLD
}

\author{
Chosinawarotin \\ Universitas Islam Balitar (UNISBA Blitar) \\ e-mail: chosinawa92@gmail.com
}

\begin{abstract}
The nature of Rahmatan lil alamin stated in the Qur'an is truly tested in the historical arena through the behavior of terrorism under the guise of Islam. The nature of this sacred concept turns into a relative and problematic necessity. Women with basic feminine characters turn fierce when trapped in the role of being a Terrorist. Harm the mother's empathy power which is actually called affection. Various facts and data recorded as social facts are then dissected to voice the potential of the actual role of women as agents of change towards peace.
\end{abstract}

Key Words; Women, Radicalism, Peace, Agents Of Change.

\section{Introduction}

In the constellation of politics in Indonesia, Islamic radicalism has experienced a sharp increase. Although radicalism movements differ in their views and objectives and do not have a uniform pattern, the reality of radicalism is an important problem to be studied today, both in the Islamic world and internationally. The complex process of Radicalism eventually gave birth to different responses to Islamic movements and activists which were divided into three variants of mention, namely; hardline variants, radicalism, and pro-violent extremism, pro-terrorism and encourage changes in the state order. Of the three variants, all of the adherents became Intolerant and Revolutionary and had the basic view that they wanted to change the social order that emphasized change in society. [1]

Reality states that the growth of various variants of this movement, both active and passive, originates from various circles. As the Center for the Study of Regional and Culture (CSRC) research at Syarif Hidayatullah State Islamic University in Jakarta, Research Coordinator Chaidar S. Bamualim shows that a number of young Muslims have been exposed to radical and extremist behavior even though the numbers are small. But from this research the most important thing then contributes to the assumption that the process of radicalization is influenced by at least three factors: identity crisis, family and friendship, and political events in the 
Islamic world. [2]

In 2006, Anne Speckhard of George Town University published an article that examined the notion of terrorism. He mentioned at least four "deadly blends" formed in a terrorist, namely: fragile personality, false ideology, social carrying capacity and public policy. The first two are family and community responsibilities, while the last two are the responsibility of the government. Family is the smallest unit of a nation and family is an important element for the growth of character and personality. The role of women in this context is that mothers cannot be justified. It is precisely from the hands of women that the great hopes of touch form the personality of a child full of compassion and tolerance can be formed. This role is ideally inspired by the values of religious teachings which traditionally have a unifying "function", because throughout empirically human history, religion has played an important role in giving a curtain of symbols that encompass everything for meaningful community integration. A variety of meanings, values and beliefs that exist in a society, finally united in a comprehensive interpretation of the elements of reality that connect human life with the world (cosmos) as a whole, so that Sociologically and Psychologically allows humans to feel at home in the universe and avoid homeless mind disease, feeling homeless or feeling lonely amidst the crowd. [3

The historical assumption that terrorism, as part of the culture of war, militarism, militancy and violence, is primarily the exclusive domination and domain of men. But in reality, the view of gender bias has been used by radical groups by using women as perpetrators of terrorism. For example, the Taliban and Boko Haram involve women as suicide bombers. [4] And the Indonesian context is a bomb of Surabaya. The natural fact of the power of mother's empathy forms love dearly hurt because self-awareness involves children taking action to destroy peaceful life. One of the important agendas of ideology alignment in looking at religious orders 
needs to be encouraged. Narratives of war that are far from compassion need to be avoided by multiplying love and affection narratives. The role of counter-radicalization that invites the stakeholder component to combat radicalism, along with moving the pattern of family approaches in preventing radicalism. This makes the importance of supporting the role of women in building social cohesion and its contribution in instilling tolerance and peace. This invites us to see what women can do as agents of change that open up the potential of women as agents of peace. [5]

\section{Women and Radicalism}

The current phenomenon of terrorists is not only an issue for men, but also for women. Although the involvement of women in acts of radicalism and terrorism is not new at all. In Indonesia the phenomenon has returned to concern after the arrest of Dian Yulia Novi in Bekasi and Ika Puspitasari who are both former migrant workers abroad. Followed by a series of Surabaya Bombings, where a woman Puji Kuswati in her role as mother had brought children who she had manipulated in a belief involved in radicalism. If the presumption of women's involvement in a number of incidents of radicalism and terrorism was due to the inequality of power relations. Risking the lives of four children is almost impossible for the imbalance of power relations to give birth to new beliefs to actively "jihad".

Because the imbalance of power relations will not give birth to full submission without signs of resistance, on the contrary the ideologization process will be able to give birth to the agency role of women in radical movements. in other words the desire of women to play a greater role is a transformation of the terrorist network. [6] Terrorism is not born in a vacuum, it grows in a culture of intolerance that continues to be echoed both in the virtual and real world. The psychological process called selfassociation with groups, according to Harvey White House, researchers from Oxford University explained that the union of identity plays a big role 
JOSAR, Vol. 1 No. 2 September, 2018; p-ISSN: 2502-8251; e-ISSN: 2503-1155

Copyrights@ Balitar Islamic University, Blitar-Indonesia

https://ejournal.unisbablitar.ac.id/index.php/josar

in encouraging people to die for their groups and religious beliefs. [7]

Without the role of mothers who have strong ideologies about the radical movement of violence, it is almost impossible for a family to be convinced to carry out a joint suicide bombing. The change in the pattern of violence is no longer from an adult male / female to a family consisting of a father, mother and child. Character education shows the role and influence of mothers in determining the attitude of intolerance is very visible, as part of the role of the service of radical women who make the body, life and family as an embodiment of ideology adopted such as the implementation of Sharia as understood. [8]

Sociologically, women are vulnerable to exposure to radical ideologies, this can be seen from the ease of accessing social media without adequate literacy skills so that they are not critical when receiving information, especially in understanding religion, women are parties who play a role in the domestic sphere. Looking at women in radicalism at first we can find several factors that become role variables, including: The Womb of the Martyrs. Domestic sector. Helping husbands to carry out Jihad and prepare logistics supplies. Educator and child character builder. Supporters of terrorism cases. Jihad on the orders of the husband/Ustadz.

Spread the call for jihad via the internet. Creator of kinship through marriage, because kinship facilitates communication. Fund raiser. But in its development it was later discovered that multifactor interplay was a reality that could not be ignored. Various factors, namely (1) Injustice and socio-economic imbalances that cause the opening of feelings of being torn and tyrannized. (2). The weakening of the basic concept of the intimacy of organic social relations which led to the widening of social distance and the murmur of ukhuwah wadhaniyah and social ukhuwah among citizens. (3). The entry (intervention) of new values from various parts of the world so as to change the cultural social values and ravage the joints of social life in the genius society. 
JOSAR, Vol. 1 No. 2 September, 2018; p-ISSN: 2502-8251; e-ISSN: 2503-1155

Copyrights@ Balitar Islamic University, Blitar-Indonesia

https://ejournal.unisbablitar.ac.id/index.php/josar

When politics mingle with their own groups, thus marginalizing the participation of the community and neglecting the common affairs, making the positive potential that should be the capital of development turn into a massive explosion that destroys the development order itself. The fact that this women's group is not only a support group, but is a major player in terrorism, is reinforced by research conducted by the Institute of Policy Analysis of Conflict (IPAC) entitled "Mothers to Bombers; The Evolution of Indonesian Women Extremist in 2017 which shows clearly the involvement of women in acts of terrorism. Since 2013 more than 100 women and children from Indonesia have crossed the Turkish-Syrian border to join ISIS.

This phenomenon shows that in terrorist networks, women have surpassed traditional roles in terms of issues, marriage, motherhood and building terrorist networks which are the traditional domains of terrorist wives in Indonesia. Women no longer see themselves as wives, mothers or even religious teachers for jihadist children, but as combatants. Furthermore, it can be said that the transformation in jihadist women cannot be separated from what they see from women in Palestine, Iraq and Chechnya. [9]

Based on data from AMAN Indonesia: Facilitating Movement in PSPP, Peace Leaders, CSO network, women's relations and terrorism at least explain the data that there are 13 names of women serving sentences for being involved in terrorism (CSAVE data). The reality of the insistence on ideology due to loyalty to the ideology of the husband is in the 39 wives of terrorist inmates carried out mentoring, because the ideology ended up being their own ideology. The tendency to give the same pattern of education to their children by entering the same boarding school with their father. Bonds with radical networks are strong because there is no programmed long from the government that ensures disengagement occurs. 
JOSAR, Vol. 1 No. 2 September, 2018; p-ISSN: 2502-8251; e-ISSN: 2503-1155

Copyrights@ Balitar Islamic University, Blitar-Indonesia

https://ejournal.unisbablitar.ac.id/index.php/josar

This is also because de radical indicators are measured based on someone's confession not by behavior change. (PRIK-UI data) $78 \%$ of 114 ISIS deportant's consisted of women and children. 151 spread in 12 provinces. 52 deportant families means that husbands, wives and children are involved in "jihad" to Syria. (Ministry of Social Affairs data). And the influence on female migrant workers comes from social media. Generally they are trapped precisely because in the search for Islam, interest through the study of radical groups in cyberspace, becomes a recruitment field and revolves around the pattern of recruiting then recruiters, finally at the same time ATMs for terrorists. Analysis of terrorist studies in addition to finding motives, usually focuses on analysis that is aligned with the main center, namely network analysis and institutional analysis.

The importance of this analysis as a means to find out and break the chain of terrorism in Indonesia, both those that correlate with the process of production and reproduction of terrorism, including in the pesantren world which is affiliated with the radicalism school. When the relationship of women in the world of terrorism becomes a relationship to consciousness as part of their ideology, Furthermore, the relationship actually has the main reality of Terrorism / Radicalism with Women's Human Rights, there are some conclusions that; The culture of gender based violence deteriorates in conflict situations or in the power of extremist groups.

confession not by behavior change. (PRIK-UI data) $78 \%$ of 114 ISIS deportants consisted of women and children. 151 spread in 12 provinces. 52 deportant families means that husbands, wives and children are involved in "jihad" to Syria. (Ministry of Social Affairs data). And the influence on female migrant workers comes from social media. Generally they are trapped precisely because in the search for Islam, interest through the study of radical groups in cyberspace, becomes a recruitment field and revolves around the pattern of recruiting then recruiters, finally at 
the same time ATMs for terrorists. Analysis of terrorist studies in addition to finding motives, usually focuses on analysis that is aligned with the main center, namely network analysis and institutional analysis.

The importance of this analysis as a means to find out and break the chain of terrorism in Indonesia, both those that correlate with the process of production and reproduction of terrorism, including in the pesantren world which is affiliated with the radicalism school. When the relationship of women in the world of terrorism becomes a relationship to consciousness as part of their ideology, Furthermore, the relationship actually has the main reality of Terrorism / Radicalism with Women's Human Rights, there are some conclusions that; The culture of gender based violence deteriorates in conflict situations or in the power of extremist groups. Violence and extremism bring the agenda of victimization to women. Sexual violence and rape are used as tools of war by groups of extremists to subjugate opponents. At this point, women are in a subordinate unfavorable. [10]

\section{Women and Peace}

The potential and contribution of women in peace does tend to be ignored, this can be strengthened by reports or narratives about women who are part of the terrorist more exposed. This means that when women's narratives that fall into the hole of radicalism are revealed more than their role in peace, this makes the urgency to look deeper into women's roles that can be done in peace (Huda, 2016). The survey conducted by the Indonesian Wahid Founder and Survey Institute conducted during October 6-27 2017 and launched in January 2018 was one of the essential steps to show the extraordinary potential for tolerance among Indonesian Muslim women to promote peace and this survey strengthened compared to 2016. Director of the Wahid Zannuba Foundantion Arrifah Chafsoh Rahman Wahid gave an analysis that in fact the role of Muslim women in Indonesia in building values of tolerance and 
peace.

The conclusion of this data is supported by the Director of the Women Development Center and the Unsyiah Aceh Lecturer Suraiyya Kamaruzzaman. [11] In this survey also included the fact of challenging Muslim women in terms of exploring their potential. The autonomous level of Indonesian Muslim women is lower than that of men. If the average score of the Muslim autonomous level is $77.7 \%$, women are only at an average score of $62.3 \%$. The confinement of Indonesian Muslim women in terms of their autonomy makes their potential as disseminators of peace values hampered. Women are often not involved in making decisions both in the family and in a more formal environment. Suraiya argues that there are at least five things that cause this; First, there is still a patrilineal culture in Indonesia. Second, religious interpretation. Third, the law has not been oriented towards the fulfillment of women's rights. Fourth, the high number of female marriages at the age of children. Still according to Suraiya how to build women's capacity can only be cut off with informal education [12]

Based on the experience of handling a number of conflicts in Indonesia, women are in fact involved in efforts to Social Reconciliation. This is confirmed by some data obtained by N-Peace, where several women were actively involved in peace efforts in Indonesia. The Story of Women of Peace in the country is a group of women who are actively involved in peace. [13] By disseminating examples of women calling for peace is part of women's inspiration regarding the growth of religious discourse and peace initiatives. If the research strategy usually goes above the expression of seeing and studying violence from religion and how religion becomes a source of violence, at the same time it relates to the interpretation of sources of texts that always display the face of violence from contemporary writers. So the image of violence that always appears on the topic of violent and violent "jihad" is seen as the way 
Muslims solve internal problems and that arise from interactions with other people. This strategy should then be changed to hold new research on binadamai and resolve the problem of non-violence in the history and practice of contemporary Muslim societies that produce harmony with reality. So that Islam emerged as "Rahmatan lil alamin" the source of love and affection for all humans. As ordered in QS Al-Anbiya '107. [14]

\section{Women as Agents of Change in Peace}

The role of women as agents of change for peace is actually inevitability and prosperity, this proposition is reinforced by three aspects that prove are: First, the first aspect is that women are naturally agents of peace. Women are given instinct to protect what is there. This is natural for every woman to protect her family. Second, the second aspect is that women can be trusted naturally. This can be proven by the trust that women receive from their children. Third, the third aspect, women as natural agents to encourage tolerance. This is at least the first mover woman, who advocates tolerance for children from home and can be brought to the outside world. Actually, Indonesia is very active in the issue of women's empowerment, both in the International and regional complexes. [15]

So why is it important to respond to radicalism from a women's perspective. This is because several important factors can be found and then analyzed together to produce solutions for various elements, namely: (1). In 2016 women still had a tendency to have high intolerance. (2). Many women are victims of Gender Based Violence during conflict or war. (3). Agenda of the Radicalism or Extremism Movement Tends to Victimize women. First, this was obtained from the AWID Report (The Association of Women in Development (AWID) 2010, explaining that this group has five agendas: Namely, 1), Intolerance and absolutism, 2), anti-women and very patriarchal, 3), Interpretation single thing that is fundamental in religion, 4). Relations with politics and power and 5). Anti-Human Rights and Freedom. 
JOSAR, Vol. 1 No. 2 September, 2018; p-ISSN: 2502-8251; e-ISSN: 2503-1155

Copyrights@ Balitar Islamic University, Blitar-Indonesia

https://ejournal.unisbablitar.ac.id/index.php/josar

Second, women from ex-terrorist families must endure stereotyping and social exclusion in their villages.

Their children are bullied at school and traumatized, so the revenge factor can be a motivation for the original group. Third, women who were bombed accompanied by AIDA for example, also experienced life changes due to disability, loss of employment, family-in-law's rejection, divorce, and so on. Fourth, 421 Discriminatory regulations collected by KOMNAS Women post-reform also victimize and even criminalize women and minorities. (4). Women are considered a second class that is easy to be used as an instrument because they are obedient, politically and loyal. In the construction of a patriarchal society, women are seen as second-class beings who must obey their husbands, including following their partner's ideology. Women are also seen as apolitical creatures, so it's not easy to suspect if they carry dangerous missions. Not only does the role of educators, recruiters, and even women become brides to carry out suicide bombings. In this case Musdah Mulia indicated that women were very friendly with religion, although religion was often not friendly to them. And the most convincing thing is that women are able to become the first fortress to protect their families in the event of unwanted things. [16]

Handling Radicalism requires expertise and cooperation from various scientific sectors. This handling is not only based on hard power based power, but problems and handling problems. [17] To support towards bette $r$ change in peace efforts. Because indeed the most central role in the fight against Terrorism remains in the policies and steps made by the government. The involvement of women is very important because they have the ability to prevent in the early stages of radicalization detection. The strategy of involving women in counterterrorism or prevention of radicalism in Indonesia can be classified in a soft power approach that involves the participation of various stakeholders and cooperation between agencies such as government, formal education, communities and 
religious groups in fighting terrorism. [18]

Partially in Indonesia, Suzanne Brenner's research indicates that Indonesian women actually have a spirit of entrepreneurship while at the same time giving support to their husbands and actively contributing to the economic and social welfare of the family as well as the community. Although it still plays a role in the position of a mother for children. Such a role is one of the ways that can prevent radicalization through the elimination of relative deprivation factors that refer to the equality of social structures in a broad sense such as poverty, low access to education, unemployment and poor housing. [19] Education is the main key in handling Radicalism. [20] Every country must place education as the most basic and most powerful way to counter radicalization. Education that promotes critical and open thinking for various possibilities must be developed to give birth to generations that are creative and open to differences. Education regarding prevention of radicalization and terrorism must have been part of the education curriculum in Indonesia since the most basic level. [21]

In the world of Indonesian women's education it has also historically been recognized to accept the same rights and freedoms as men. So that the involvement of Indonesian women in all policies and improving the condition of the public and the state can be justified culturally and socially. Because radicalization can take the form of non-violence so that nonviolent approaches where the mainstream society still identifies tenderness and femininity are more owned by women, will be more effective as a social and psychological reason. The inclusion of women in the public sphere and in the production of a reinterpretation of religious texts in making women active in fighting radical ideology. With the range of roles played by women from the domestic to the public, women's role in combating radicalization will be very the use of Soft Power (soft-based power) will be very important to be involved, for example giving space to 
JOSAR, Vol. 1 No. 2 September, 2018; p-ISSN: 2502-8251; e-ISSN: 2503-1155

Copyrights@ Balitar Islamic University, Blitar-Indonesia

https://ejournal.unisbablitar.ac.id/index.php/josar

ministries and non-military or non-police institutions to be involved together in formulating prominent, including from the early stages in the form of anticipation and prevention of the radicalization process. [22]

Some feminist organizations in Indonesia that are religiously based, such as Fahmina Institute, Rahima, Puan Amal Hayati and Kalyanamitra through various programs, one of which is the regeneration of female clerics, has included in the strategy to re-read the Qur'an and reinterpret the main sources of Islamic law maintain the ideas of gender equality and justice. Also various religious organizations such as Aisiyah Muhammadiyah, Muslimat NU, National Women's Commission as state agencies are also actively fighting for gender equality through moderate education and advocating for elimination of gender discriminatory laws and regulations as an effort to prevent radicalization of religious ideas and acts of terror. [23]

\section{Involvement Of Women In Radicalism And Peace In The Study Of Sociology}

Peace building and handling radicalism / terrorism are the main problems of the entire community. This analysis of the community and not the individual is a working field of sociologists as social thinkers. What is said to be typical as a sociological analysis is when discussing social systems, norms, values and social roles with the foundations laid in sociology. In the view of classical Sociology, society is defined as a unity of interdependent mechanisms that ensure integrated or interdependent combinations of elements that are in opposition between individualism of actors and the internalization of institutionalized norms for the purpose of Collective Integration. [24]

When moving on to discuss efforts to ward off terrorism or radicalism in the framework of peace, this is then where reading is turning to the area of peace and conflict. In the end we can at least look at conflict theory and structural functionalist theory as a paradigm of a social fact. 
when structurally functionalist ideally the community is in a static (order) or dynamic (progress) condition in the community from the results of general research on the basis of social stability. Comte sets the basic functionalism assumption regarding social system interdependence, when he states that static studies of sociology include the investigation of the laws of action and reaction of various social systems. The concept of functional balance arises when he declares that the obstacle of creating harmony between all and parts of the social system is "pathology". The concept of balance is borrowed from the biological treatment of homeostasis. For example, if one part of the body is sick, other parts of the body will be affected and feel pain, so it needs to be treated so that balance returns to the body. This Comte thought is an analogy between the social system and biological organs. [25]

When each element or institution is obliged to provide support for stability, and the perspective of community members is informally bound by the norms of general values and morality. And surely here we are talking about the ideality of a meaning of peace. Where the absence of structural violence or the creation of social justice, which includes all aspects of a good society, such as the fulfillment of universal human rights, economic welfare, ecological balance and other core values. In conflict theory, seeing society is in a process of change which is characterized by continuous opposition among its elements and sees that each element contributes to social disintegration and assesses the order contained in society only because of pressure or force from above by groups that in power. The central concept of this theory is authority and position which are social facts. [26]

Conflict theories argue that concepts such as real interests and latent interests, pseudo interest groups and groups, positions and authority are the basic elements to explain the forms of conflict. Under ideal conditions there are no other variables needed to explain the causes 
JOSAR, Vol. 1 No. 2 September, 2018; p-ISSN: 2502-8251; e-ISSN: 2503-1155

Copyrights@ Balitar Islamic University, Blitar-Indonesia

https://ejournal.unisbablitar.ac.id/index.php/josar

of social conflict. In non- ideal conditions there are still several factors that can influence the process of social conflict. Among the technical conditions with sufficient personal, political conditions with normal temperatures, social conditions with the chain of communication. Another factor that concerns the way of forming pseudo groups. From conflict can contribute to integration and vice versa from integration can also produce conflict. The final aspect of conflict theory is the link between conflict and social change. Conflict leads to change and development. Between structural functionalists and conflict, these two theories are both holistic in the sense that they both see society as interrelated parts. By discovering the facts from the viewpoint of sociology on terrorism as described above, it has emerged why they are committing terror. From this fact, an analysis of change will be found that focuses on what should be addressed.

Each individual should not turn a blind eye to the conflict represented by terrorism, as ordered by functional theory, when faced with a social change, the public is visually experiencing a dynamic but its ideal is always in balance. If then the discourse of peace revolves around this to sharpen the point of view in understanding terrorism as a source of conflict so as to find the best solution. Religious conflicts then should not be exaggerated or even used as a tool to attack a particular religion. Or rather the sensitivity to the issue of religion then gave rise to apathy towards the problem of terrorism, due to fears of radical labeling. Talking about peace compared to the discussion of a conflict is actually the hope of the effectiveness of a solution that is a necessity, because Indonesia is growing in diversity. And from Berghe himself dismantling there is always a function even though it is in the realm of conflict, the four functions are as a means of maintaining solidarity, helping to create alliances with other groups, activating the role of the initially isolated individual, and communicating functions. [27]

The Terrorist movement that uses the Religious Cloak to hide the 
motives in it, if seen more deeply the real victims are actually from the Muslims themselves. Various data must be read from a broader perspective, this is to find the results of mapping between interests and groups as in the theory of conflict, because ultimately it leads to the conditions of various countries' divisions above the religious line, so that they are weak and can be controlled. This is what the functionalist theory says, where conflict can benefit one party and harm the other. Understanding of the roots of the movement is very necessary to make a policy and tactical steps to overcome it. Facing Terrorism issues requires a comprehensive approach, to face very serious global challenges. Based on the previous discussion with the community role approach, the role of economic and educational aspects, policies and regulations.

Judging from August Comte's perspective, individuals are influenced and shaped by the social environment, so that basic community units are not individuals but families. In the family individuals are introduced to society. Comte wants to create a positive society in the sense of progress and based on social order. [28] Peace is a necessity in the midst of diversity and differences in interests among the people who indeed must continue to run above balance. Family is the smallest unit in a nation. From the family it is individual and individual growth that cannot be separated from the role of a woman who is a woman. Women have great potential to be involved as part of soft power-based forces to deal with the problems of Radicalism and terrorism. With the program as a policy maker, educators, community members and activists, established peace schools, incubators of grassroots female leaders. Where the incubation of grassroots female leaders, community-based learning, women across faith, commitment to learning to strengthen discourse and conflict transformation and peace building skills. Printing local facilitators in peace with the target of change is family, community, structural and cultural. 
JOSAR, Vol. 1 No. 2 September, 2018; p-ISSN: 2502-8251; e-ISSN: 2503-1155

Copyrights@ Balitar Islamic University, Blitar-Indonesia

https://ejournal.unisbablitar.ac.id/index.php/josar

\section{Conclusion}

The occurrence of new trends in the world of Terrorism that involve families as the events experienced by Indonesia in Surabaya increasingly require the role of women in the struggle against Terrorism. The importance of women's involvement in the prevention of armed conflict and other conflicts, the importance of protecting victims of conflict. The importance of women's participation in conflict resolution, the importance of recovery rehabilitation is an agenda of changing women's roles in preventing radicalism towards peace and security. If the root problem of Radicalism is injustice and this imbalance cannot be solved in the short term and this most appropriate treatment is through government programs. By involving women as a soft power base in handling Radicalism, it is easier to recognize, see what happened and trace to obtain complete data as a step to deal with Radicalism. The big role of women in instilling values in the family so that a significant role in the formation of a positive perspective. This makes empowering and developing women very important for peace. Women's initiatives as agents of change in peace as a Soft Approach for the struggle against terrorism, this initiative is to spread the values of peace and tolerance and be accompanied by empowerment in local communities, especially in the economic sector and the promotion of non-formal education. Increasing positive values and welfare will be a strong shield against the influence of radicalism and intolerant values. An interesting thing to be noted further is that the Soft Approach of women's relations with the involvement of religious communities such as Muslimat NU or Aisyiah Muhammadiyah is a means of Social Transformation which is actually easy and effective to build empowered women and peaceful communities, as a stronghold of family resilience that can sustain national resilience.

The sociology approach is an approach that can be used to view this Radicalism perspective. In the midst of a conflict situation, the 
JOSAR, Vol. 1 No. 2 September, 2018; p-ISSN: 2502-8251; e-ISSN: 2503-1155

Copyrights@ Balitar Islamic University, Blitar-Indonesia

https://ejournal.unisbablitar.ac.id/index.php/josar

presence of human peace is urgently needed. Human peace does not sink into And the ability to empathize is owned by human peace without reducing rational understanding. They can still do the analysis of problem solving, understanding the root of the problem and carrying out the steps needed to solve the problem, so that from this empathy then comes into cooperation.

\section{References}

[1] Tinka Veldhus and Jorgen Staun, Islamic Radicalization: Model Causes of Roots, Den Haag; Institute for International Realization of the Netherlands Clingendael, 2009.

[2] Measuring the Radicalism of Young Muslim Activists, Kompas.com, February 23, 2018.

[3] Peter L. Berger, Brigitte Berger and Hansfried Kellner, Pluralisation of the World of Life, in Hans Dieters Ever (peny), Society Theory; Process of Civilization in the Modern World System, Jakarta; Indonesian Torch Foundation, 1998, h. 49-51.

[4] J. Zenn and E. Women Pearson, "Developing Gender and Tactics of Boko Haram", Journal of Terrorism Research, 5 (1) (2014).

[5] Lies Marcoes, Feminization of the Radical Movement, Jawa Post; May 16, 2018.

[6] Lies Marcoes, Feminization of the Radical Movement, Jawa Post May 16, 2018.

[7] Reasoning the Role of Terrorism, Kompas.com, January 17, 2017.

[8] Lies Marcoes, Reasoning the Role of Female Terrorists Behind Suicide Bombings in Surabaya, Kompas.com, May 14, 2018.

[9] Understanding Peace Building Through Women, Kompas.com, March 22, 2018.

[10] Ruby Kholifah, Women and Radicalism in Indonesia, Building sustainability through the Role of Women, www.amanindonesia.org, November 14, 2017.

[11] http://nasional.kompas.com/read/2018/01/30/12590711/women-muslimindonesia- and-challenge-being-agent-peace / Wednesday February 07 $2018 \mid$ 10:35

[12] http://nasional.kompas.com/read/2018/01/30/12590711/women-muslimindonesia- and-challenge-being-agent-peace / Wednesday February 07 2018 | 10:35

[13] Dian Indraswari, Ruby Kholifah, Hidden Pearls, Heroic Story of Women Pioneer of Peace, United Nations Development Program (UNDP) Indonesia, December 2016.

[14] When Religion Brings Peace, Not War, Learns from Imams and Priests, 
JOSAR, Vol. 1 No. 2 September, 2018; p-ISSN: 2502-8251; e-ISSN: 2503-1155

Copyrights@ Balitar Islamic University, Blitar-Indonesia https://ejournal.unisbablitar.ac.id/index.php/josar

editor of Ihsan Ali Fauzi, PUSAD Paramadina, Jakarta, 2017. Marcheilla Ariesta, Agent for Women's Change for Peace, Metro TV News.Com, November 30, 2017.

[15] Ruby Kholifah, Women and Radicalism in Indonesia, Building sustainability Philosophy, Bandung; Pustaka Setia,2008.

[16] hrough the Role of Women, www.amanindonesia.org, November 14, 2017

[17] Huda, A. M. (2016). THE IDENTITY OF JAVANESE WOMEN (The study of Phenomenology Toward Indonesian Migrant Women Workers). Journal of Academic Research and Sciences (JARES), 1(1), 2016. 